Article

\title{
Lessons from the First Wave of COVID-19. What Security Measures Do Women and Men Require from the Hotel Industry to Protect against the Pandemic?
}

\author{
Ramón Rueda López ${ }^{1}$ (D), Teresa López-Felipe ${ }^{1, *}$, Virginia Navajas-Romero ${ }^{1}$ (D) and Antonio Menor-Campos ${ }^{2}$ (D) \\ 1 Department of Statistic, Econometrics, Operational Research, Business Organization and Applied Economics, \\ University of Cordoba, 14071 Córdoba, Spain; ramon.rueda@uco.es (R.R.L.); vnavajas@uco.es (V.N.-R.) \\ 2 Department of Agrarian Economy, Finance and Accounting, University of Cordoba, 14071 Córdoba, Spain; \\ es1mecaa@uco.es \\ * Correspondence: mtlopez@uco.es
}

check for updates

Citation: Rueda López, R.;

López-Felipe, T.; Navajas-Romero, V.; Menor-Campos, A. Lessons from the First Wave of COVID-19. What Security Measures Do Women and Men Require from the Hotel Industry to Protect against the Pandemic? Int. J. Environ. Res. Public Health 2021, 18, 2232. https://doi.org/10.3390/ ijerph18052232

Academic Editors: Michael McAleer, Chia-Lin Chang, Daniel J. Slottje and Teodosio Pérez Amaral

Received: 27 October 2020

Accepted: 19 February 2021

Published: 24 February 2021

Publisher's Note: MDPI stays neutral with regard to jurisdictional claims in published maps and institutional affiliations.

Copyright: (C) 2021 by the authors. Licensee MDPI, Basel, Switzerland This article is an open access article distributed under the terms and conditions of the Creative Commons Attribution (CC BY) license (https:// creativecommons.org/licenses/by/ $4.0 /)$

\begin{abstract}
The tourism sector in general and the hotel sector in particular face the challenge of managing appropriate security measures to deal with the COVID-19 pandemic. In this sense, it is useful to know which measures are most demanded by the clientele. This research, through non-parametric statistics tests, concluded that women are more demanding than men in relation to the security measures to be taken in hotels. More specifically, this research concludes that women are more demanding than men in relation to a set of measures including ensuring good hygiene conditions, the use of disinfectants, the existence of health and information checks, adapting the establishment to WHO recommendations, obtaining quality certification, measuring temperature, the need to provide information on protocols and measures, and the elimination of physical contact between people. This, as a practical application, makes it possible to know more accurately about the safety requirements of sex-segmented customers in the face of future health crises, allowing tourist managers to offer safer destinations and the hotel sector better health conditions for their clients.
\end{abstract}

Keywords: COVID-19; tourism; hotel sector; security measures; sex differences

\section{Introduction}

On March 11, 2020, the World Health Organization (WHO) declared a global pandemic caused by the SARS-CoV-2 coronavirus strain [1]. This pandemic spread globally within a few months, affecting economic and social aspects around the world. Travel bans and social estrangement are recurrent public health guidelines in pandemic containment and have had a major impact in industries with high levels of human interaction or "high contact" [2], such as hotels or other tourist activities, hard-hit in this period [3]. However, the pandemic of the COVID-19 is not the first health crisis affecting travel in particular and tourism in general. In recent decades, other viral epidemics such as severe acute respiratory syndrome (SARS), also known as SARS-CoV-1, MERS, swine flu, Ebola, Zika, or yellow fever have also threatened public health around the world [4]. Unlike health problems such as the 2003 SARS outbreak or the Ebola crisis of natural disasters [5-9] or of social revolts such as the Arab Spring [10], the COVID-19 pandemic is a reality. However, according to Lori Pennington-Gray, director of the Tourism Crisis Management Initiative, it is the first time that a health crisis (or of any other type) has become a global crisis and is affecting all countries of the world and all facets of tourism activity [11].

Paradoxically, tourism activities, and especially travel, have become a vehicle for the diseases likely to become pandemics; therefore, tourism is the sector most affected by actions designed by the public health authorities for the mitigation of the pandemic [9]. The connection between tourism services and the risk of health disasters has forced governments to restrict, or even prohibit, travel as a measure for managing the risks posed by the transmission of the virus $[1,9]$. 
Air transport is currently the main means of pandemic spread [12]; hence, the measures taken to minimize SARS transmission between March and May 2003 focused on reducing passenger numbers at the major airports concerned. This reduction was between $57 \%$ and $77 \%$ [12].

This has happened in other health crises. In 2009, there was a reduction in passenger volume of between 4.12 and $7.88 \%$ due to swine flu. However, as a differentiating element, in the case of avian influenza, in 2006, passenger volume in affected areas increased by $9.04 \%$ to $16 \%$. In these three previous pandemics, measures such as taking the temperature of travellers were adopted at airports, containing travellers with symptoms. In fact, the responses given by countries in the current pandemic have followed protocols similar to the authors $[13,14]$. However, there are aspects that differentiate the current pandemic from the previous ones in terms of its effects and the scope and effectiveness of the measures taken to contain them, such as the life cycle of pathogens caused by quarantine situations. According to the experts, the lack of preparation of the tourism industry in the current situation could be explained by the differences in the COVID-19 pandemic in relation to those mentioned above since these did not have a significant impact on the decline in international travel [9]. On the other hand, the incubation period of the other pandemics was shorter and more noticeable compared to COVID-19's, which has made it sometimes undetectable. That characteristic has facilitated its spread via travellers [15].

Specifically, within the tourist sector, the hotel is one of the most vulnerable to the effects of the COVID-19 pandemic [16,17].

In Spain, according to data published by the National Statistics Institute (NSI) - the independent administrative autonomous institution assigned to the Ministry of Economic Affairs and Digital Transformation-overnight stays in hotel establishments decreased by $78.4 \%$, the average stay for each visitor was shorter by $31.28 \%$, and the occupancy rate at bed-places was $60.45 \%$ lower than the same month of 2019 [18].

In this regard, as Shin and Kang [19] point out, there is a high perception of the risk of destinations and hotel properties. For this reason, it is necessary to address, within the hotel industry, the study of the necessary actions that can defuse the effects of the pandemic on the hotel sector. As Jiang and Wen [20] show, it is appropriate to define strategies and actions that promote the confidence of guests, supporting the recovery of the sector. However, a scenario is possible where the hotel industry can be more resilient and sustainable from the security needs of guests, adapting them through measures that can transform threats into opportunities [20].

Finally, the adjustment of the expectations placed by the World Tourism Organization (UNWTO), from predicting on 6 March 2020 a two to three percent reduction in international travel is significant, compared to the 2019 figures, to a 20 to $30 \%$ reduction announced by 26 March 2020 [9], which in subsequent months was increasing.

The objective of this research is to present the results of a study carried out in Spain to identify the perceptions and opinions that women and men have with regard to tourist destinations that are marked by this pandemic.

Research on gender differences in the tourism sector has been conducted from various points of view, such as the image of the destination and travel options [21], the commitment and loyalty of the visitors [22], the risks [23], and, more specifically, in tourist areas such as golfing locations [24], archaeological sites [25], or World Heritage sites [26].

Moreover, recent research has addressed the impact of COVID-19 on tourism. These studies include those of Roman et al. [27], who confirmed the great impact of the COVID-19 pandemic on the organization of tourism travel during 2020; Hong et al. [28], who have studied the impact of the pandemic on the bed and breakfast $(B \& B)$ tourism industry in China; or that of Han et al. [29], who revealed that corporate social responsibility in the tourism sector improves attitudes and behavioural intentions of passengers or guests.

In our case, this investigation, in particular, aims to check whether there are differences between women and men in terms of the safety measures required by each group to deal with the hotel sector in order to deal with the COVID-19. This will be analysed through 
a segmentation by gender which will enable a better understanding of the needs and expectations of both population groups in reaction to the measures required to protect tourists from COVID-19 in the hotel sector.

Achieving this objective makes it possible to better understand the expectations that women and men have separately in terms of security. Something relevant if the rational decision-making process for the purchase of tourist goods and services is considered to be different between women and men [30]. Women, in this regard, are often more sophisticated consumers, paying greater attention to details [31,32].

The findings and conclusions that can be obtained from this research may be of particular interest for the hotel sector, allowing managers of these establishments to design and manage security measures that make their guests feel safer in future waves of the pandemic, thus obtaining a return of women's opinions regarding the risks perceived during travel [23].

To achieve this objective, this research is organised as follows: First, we present backgrounds on the impact and consequences of COVID-19 on tourism, on the possibility and challenges identified to address the pandemic in the tourism sector, the way in which differences between women and men in the tourism sector have been addressed, and the safety measures to be taken against COVID-19 in the tourism sector; these backgrounds will serve to define the hypothesis of the research. Next, we present the methodology of the investigation. This is followed by a section in which the results of the investigation are presented and analysed and, finally, the conclusions paragraph summating the findings of the investigation will be presented.

\section{Background}

\subsection{On the Impact and Consequences of COVID-19 on Tourism}

The impact of COVID-19 and its consequences on tourism depend on factors marked by uncertainty, which can be grouped into three categories: first, the duration of the crisis (pandemic control, travel restrictions, reactivation of transport, control of successive waves of COVID-19, etc.); second, the support policies that governments implement (who the beneficiaries will be, how effective these policies will be, etc.); and third, the kind of tourist behaviours that arise (if consumers decrease or intensify their desire to travel; the role that confidence among tourists will play in nations or areas as a tourist destination, how health and safety are perceived, etc.). These three categories of external factors are complemented by situational factors in each of the destinations, such as dependence on tourism, proper governance of the destination at different levels, or the willingness to adapt to different tourist behaviour [33].

There are also voices that say nothing will ever be the same again in tourist activity and the high likelihood that the socio-economic changes produced by this pandemic will have a very significant impact on tourism in aspects such as mobility, patterns of socialization and consumption, or the relationship between leisure and work [34]. The UNWTO estimated a decrease of between 20 and $30 \%$ in international tourist arrivals and corresponding economic income in 2020 compared to 2019. However, the UNWTO recognizes that such estimates should be treated with considerable caution, given the magnitude, volatility, and completely different profile of this health crisis compared to previous pandemics [35].

\subsection{On Possibilities and Challenges to Face the Pandemic}

The pandemic of the COVID-19 virus is causing a huge problem for tourism activity in all countries and it is unknown how the tourism sector will develop afterwards, in a period of economic and social crisis. Therefore, the key question, which is the objective of this research, is what tourists will demand in terms of safety measures when they can travel again, and for this question, there are several answers that are related to the transformation that the COVID-19 pandemic will provoke in tourist activity.

From the scientific research perspective, the transformative potential of the pandemic towards sustainability is emphasized, reconsidering a global tourism system more aligned 
with the United Nations Sustainable Development Goals (SDG) [8,9,36]. Thus, the importance of a tourist model aligned with the SDG should be focused on sustainability and people as a question of coherence and justice, with a technical and political basis in line with the achievement of the SDGs and to mark the roadmap to the new future of tourism [37].

The post-COVID-19 tourism model must have a developed learning capacity and be able to anticipate future crises with new priorities and needs of the population and tourists [38].

Sustainability refers to how specific models of ecological partner systems respond to disturbances [39]. It tries to respond to how tourism can adapt to the social, political and economic change that is causing this pandemic [40].

The UNWTO's approach [35] is broader and concerns the SDGs and resilience along with institutional strengthening to mitigate the impact of the health crisis and accelerate economic and social recovery. This recovery is based on the following resilience principles set out by Biggs et al. [41] and applied by Berbes-Blazquez and Scott [42]:

(a) Diversity and redundancy: different types of attractions, different groups of objectives to combat vulnerability and overcrowding, organization of events, etc.

(b) Connectivity: the links of a tourism system, which requires networks at various levels from aviation for international tourism to land transport for local tourism.

(c) Management of slow variables and feedback: slow variables report on the dynamics of a system, such as the diverse and changing preferences of tourists, while fast ones do so about the flow of tourists.

(d) Experimentation and learning: development of new forms of tourism and innovative offers, tourism destination management teams to promote research and the learning of tourist patterns.

(e) Central participation and governance: meeting of the various stakeholders, citizens and experts, to improve decision-making, and the independence of units acting with vertical and horizontal links.

The aftermath of COVID-19 in the tourist activity anticipates the emergence of new tourist consumption habits and patterns based on greater social and environmental awareness [6,43], which will show consumer concern about sustainability and social problems, both nationally and internationally [43-47]. Consequently, post-COVID 19 tourists will choose to travel to destinations that are closer to their place of residence and safer.

In the context of insecurity and uncertainty, nearby destinations could be considered "less risky" by many potential tourists who, having been remarkably affected by the social and economic crisis arising from the health crisis, have seen their purchasing power reduced. Added to this are restrictions on international (long-distance) travel, at least for a while, to help reduce air pollution, which would undoubtedly be in line with the promotion of more sustainable tourism and the development of the concept of decline. In this regard, greater adaptation to future pandemics of those companies that adapt to the expected change in the consumer, which will include a greater demand for sustainable tourism, is expected [43]. This implies that tourism companies must be strongly rooted in the destination, that have been loyal to the principles of sustainable tourism, that offer ecotourism products or based on the local natural and cultural heritage, that provide high-quality experiences for tourists and that achieve an added value for the destination and, logically, for the local community itself, and all of this with maximum health safety.

As a result, a paradigm shift for post-COVID-19 tourism will replace the market share approach with one based on value-sharing and where the marketing of tourism companies has to be oriented to listen to what people want and are passionate about in order to share and satisfy those desires [48].

The challenges that arise in the post-COVID-19 world challenge tourism stakeholders to develop transition plans with scenarios incorporating sustainability, resilience, and internationalization [33]. Therefore, the work that arises on the role of robotics and the development of technology in the adaptations necessary to deal with the safety and hygiene 
measures imposed by the pandemic in airports, shopping centres, tourist accommodation, or restaurants [49] is necessary. Also necessary is scientific research on the adaptation of tourist cities with models and techniques based on robotics and computing, and that represent the context of a particular application of resilience [50], estimating the spread of COVID-19 in meaningful urban contexts [51]. It will also be necessary to take into account the implications of the pandemic on information systems and in the proactive collection of data for knowledge of future tourist demand based on the use of big data and not on historical data [52].

\subsection{On the Differences between Women and Men in Tourism}

Sex is an important variable to consider in the behaviour and ways in which consumers make their decisions [53]. In this regard, it is appropriate to visualize the views that women, as a group, may have, since they are increasingly important as consumers in general [54] and as consumers of tourist products in particular [31]. In relation to this, men make decisions more quickly and intuitively, while women take into consideration the views of their families and friends [55] and, as Karatsoli and Nathanail pointed out [56], are influenced by their social networks.

However, taking as a reference the sex variable to identify differences in relation to the motivations, the experiences or satisfaction of tourists who, for example, visit a heritage site of humanity, creates dispute.

Research such as that of Adie et al. [57], Chen and Huang [58], and Correia et al. [59] identified no sex differences, while the research of Ramires et al. [60], Wang et al. [61], and Huete-Alcocer et al. [62] did, noting that women are more willing to visit heritage destinations. On the contrary, Wang and Hao [21] argue that it is men who have the greatest predisposition to visit historical sites.

However, sex differences regarding measures required by the tourist sector in general and the hotel sector in particular to address COVID-19 have not been thoroughly investigated.

For a city that, for example, bases its tourism on historical and cultural heritage, knowing these differences between sexes is relevant for two reasons.

First, because the rational decision-making process for the purchase of tourist goods and services is different between women and men [30]. Women are usually more sophisticated consumers and pay greater attention to details [31,32]. For this reason, it seems appropriate to determine what differences between sex may be in order to enable local tourism plans and the hotel sector to provide preventive measures against COVID-19 that meet the expectations of women and men separately [26].

Second, according to Wang and Hao [21], women have less of a predisposition than men in the choice of heritage tourist destinations. Therefore, analysing separately what the most-demanded security measures are for women and men in relation to COVID-19 may be important in providing a safer and more attractive tourist destination.

Thus, under the aim of the research and taking into account the revision of literature, the hypothesis that can be drawn is hypothesis 1) The level of requirements for security measures in hotel establishments is different between women and men.

\subsection{On Security Measures in Tourism against COVID-19}

The pandemic has paralyzed tourism globally and its relaunch at the so-called "new normal" stage requires a balance between maintaining a satisfactory experience for tourists and complying with the strict measures taken by the authorities on safety and hygiene to ensure a reactivation of the tourism industry once the containment phase has passed. Thus, in mid-May, the World Travel and Tourism Council (WTTC) presented the global protocols for the revival of the tourism sector with the claim of building consumer confidence, recovering jobs, and compensating for the financial losses caused by the fall in tourism worldwide. The protocols capture measures that have been designed by all industry representatives worldwide and are based on medical evidence, standards established by the World Health Organization (WHO) and the Centers for Disease Control and Prevention 
of the U.S. Department of Health \& Human Services (CDC). They constitute a means of approval of criteria and provide health guidance to suppliers, travel operators, and tourists.

Regarding tourist accommodation, and specifically hotels, these protocols and recommendations have been the subject not only at a global scale but also by the European Commission, through the communication for the progressive restart of tourism services and health protocols in hospitality establishments (2020/C 169/01), published in the Official Journal of the EU of May 15, 2020 [63], and of national governments; in the case of Spain, it has been formalized in a document prepared by the Institute for Spanish Tourism Quality [64] in coordination with the Secretary of State for Tourism, the Autonomous Governments of the Spanish regions and the Spanish Federation of Municipalities and Provinces. According to all of them, the measures and recommendations designed for their development and application in hotel establishments have generally been realized in processes of deep cleaning and hand washing, between staff and customers, and use of protective equipment (masks, gloves and other protective measures); cleaning and disinfection of common spaces and contact points such as railings, tables, handles, sinks, etc.; disinfection of room cards, TV controls, light switches, and thermostats as well as the promotion of electronic payment; installation of alcohol-based hand-sanitizer dispensers on each floor, in entrances and outlets; cleaning and reduced capacity in elevators; as well as encourage the use of stairs; in-room breakfast delivery, if possible, and a guarantee in buffets that guests do not handle food. They also point to the importance of assigned seating plans in common areas to avoid physical contact and agglomerations, as well as clear information and signage; limitation of capacity, social distance and identification of risk zones in entrances and points of greater influx; completion of risk assessment questionnaires before accessing the establishment; reservation of isolation spaces in the hotel itself for users presenting symptoms of COVID-19 during their stay.

In relation to the above measures, it is worth noting the study carried out in hotels in the Canary Islands [65] whose results on the changes that the pandemic has brought in tourist accommodation reveal that the protocols implemented will be sufficient for the reopening of tourism, that the greatest adaptation efforts are concentrated in the common areas, areas of restoration and cleaning of rooms. The most important measures related to common areas are social estrangement and the use of personal protective equipment (PPE) by workers, while major re-opening investments focus on protective equipment and signage to organize customer transit, followed by the placing of protective screens.

The proposed objective for this research is to determine the extent to which sex differences exist in terms of measures required against COVID-19 by tourists in the hotel sector; therefore, taking into account the revision of the literature carried out in the contrast scenarios, the hypotheses are as follows:

Hypothesis 1. The level of demand for respecting social distance in hotels is different between women and men.

Hypothesis 2. The level of requirement regarding the good hygiene conditions that a hotel must present is different between women and men.

Hypothesis 3. The level of demand for the information that hotel employees must have in front of COVID-19 is different between women and men.

Hypothesis 4. The level of demand for avoiding physical contact within a hotel is different between women and men.

Hypothesis 5. The level of demand for using the mobile phone to register at the hotel is different between women and men.

Hypothesis 6. The level of demand for considering the importance of hotels being "immune" is different between women and men. 
Hypothesis 7. The idea that it is better to stay in small hotels is different between women and men.

Hypothesis 8. The idea that the hotel should deliver a virus prevention kit is different between women and men.

Hypothesis 9. The idea that the use of $Q R$ codes should be extended in hotels is different between women and men.

Hypothesis 10. The idea that disinfectants such as ozone should be used in hotels is different between women and men.

Hypothesis 11. The idea that there should be health checks in hotels is different between women and men.

Hypothesis 12. The idea that official information should exist in hotels is different between women and men.

Hypothesis 13. The idea that hotels should adapt to World Health Organization (WHO) recommendations is different between women and men.

Hypothesis 14. The idea that hotels should have a quality certification for coronavirus prevention and control is different between women and men.

Hypothesis 15. The idea that hotels should measure the temperature of customers is different between women and men.

Hypothesis 16. The idea that hotels should inform customers about protocols and measures is different between women and men.

Hypothesis 17. The idea that hotels should eliminate physical contact between staff and customers is different between women and men.

\section{Methodology}

\subsection{Data Collection}

The methodology used in this research is based on the realization of a field work to a representative sample of people in Spain to know their opinions and perceptions of what tourism will look like after the pandemic.

The data collection process was conducted through an online survey disseminated by general social networks and specialised in tourism. Fieldwork was carried out between April and June 2020. This research collected a total of 332 responses, of which 328 were valid.

A non-probabilistic technical sampling technique was used, commonly employed in this type of research where interviewees are available for surveys in a given space and time [66]. The survey, as it was carried out online, addressed, in particular, those people who are active in social networks specialized in tourism and travel. No stratification of the sample was carried out by age, education, nationality, or by any other variable as there were no previous studies that supported this stratification.

To test the reliability of the scale, Cronbach's Alpha test was performed, yielding a value of 0.830 , a value above the minimum limits of 0.7 set by Nunnally and Bernstein [67].

\subsection{Survey Questionnarie}

The quantitative methodology used in this research has been based on a questionnaire based on previous studies [65,68-70]. The questionnaire was completely anonymous and was divided into three clearly differentiated blocks. The first block addressed questions related to the respondent's way of making the trip. The second of the blocks addressed 
aspects that looked at the measures taken in hotels and how this pandemic can affect the tourist experience in a given destination. The third block addressed the sociodemographic profile of respondents where aspects such as sex, age, level of study or household income were analysed.

The questions included within the second block were asked through five-point Likert scales, where 1 referred to "Very much disagree," 3 "Neither disagree nor agree" and 5 "Very much agree". The questions included in the first and third blocks were closed.

As noted above, this research is specifically intended to check whether there are differences between women and men in the safety measures that each group requires the hotel sector to deal with COVID-19. To achieve this objective, only the responses obtained in the second and third blocks of the survey have been taken into consideration. Appendix A presents the question that has been used in this investigation as a contribution to further investigations.

\subsection{Data Analysis}

By calculating the means that both women and men have given to each answer, it is possible to accept or reject the research hypotheses. In this regard, the interest of research, as already justified, is to identify differences between women and men. Incorporating other study variables such as the level of studies, income level or country of origin, will remain for future research addressing a multivariant-type analysis.

Both for the preliminary analysis of data, processing and tabulation, as well as the corresponding statistical analysis, used the SPSS V.25 statistical software (IBM Corporation, Armonk, NY, USA) [71].

\section{Results and Discussion}

\subsection{Sociodemographic Profile}

According to the data presented in Table 1, it can be concluded that the profile of the model person who has participated in this study is that of a young woman residing in Andalusia (Spain) who is a full-time employee or student, and has an income that can range from 1000 to 2500 euros per month.

Table 1. Socio-demographic profile.

\begin{tabular}{|c|c|c|c|c|c|}
\hline \multicolumn{2}{|c|}{ Variable } & \multirow{2}{*}{$\begin{array}{c}\% \\
40.60 \%\end{array}$} & \multicolumn{2}{|r|}{ Variable } & \multirow{2}{*}{\begin{tabular}{c|}
$\%$ \\
$7.43 \%$
\end{tabular}} \\
\hline Sex & Men & & \multirow{10}{*}{$\begin{array}{l}\text { Professional activity } \\
\qquad N=269\end{array}$} & Liberal professional & \\
\hline$N=266$ & Women & $59.40 \%$ & & Entrepreneur & $4.46 \%$ \\
\hline & Less than 20 & $35.37 \%$ & & Public servant & $22.68 \%$ \\
\hline & Between 20 and 29 & $24.70 \%$ & & Full-time employee & $24.16 \%$ \\
\hline Age & Between 30 and 39 & $10.67 \%$ & & Part-time employee & $4.09 \%$ \\
\hline$N=328$ & Between 40 and 49 & $8.84 \%$ & & Self-employed & $3.72 \%$ \\
\hline & Between 50 and 59 & $16.16 \%$ & & Student & $25.28 \%$ \\
\hline & More than 6 & $4.27 \%$ & & Unemployed & $5.95 \%$ \\
\hline \multirow{12}{*}{$\begin{array}{l}\text { Region } \\
\mathrm{N}=262\end{array}$} & Andalusia & $66.79 \%$ & & Retired & $1.12 \%$ \\
\hline & Community of Madrid & $7.63 \%$ & & Household work & $1.12 \%$ \\
\hline & Basque Country & $4.58 \%$ & \multirow{4}{*}{$\begin{array}{l}\text { Education level } \\
\qquad N=268\end{array}$} & Primary & $2.24 \%$ \\
\hline & Outside Spain & $4.58 \%$ & & Secondary Education & $19.40 \%$ \\
\hline & Extremadura & $3.82 \%$ & & University degree & $41.42 \%$ \\
\hline & Castilla La Mancha & $2.67 \%$ & & Postgraduate/Master's/PhD & $36.94 \%$ \\
\hline & Catalonia & $2.29 \%$ & \multirow{6}{*}{$\begin{array}{c}\text { Income }(€ / \text { month }) \\
N=262\end{array}$} & Less than 700 euros & $4.96 \%$ \\
\hline & Asturias & $1.91 \%$ & & From 700 to 1000 euros & $11.83 \%$ \\
\hline & Canary Islands & $1.53 \%$ & & From 1001 to 1500 euros & $24.81 \%$ \\
\hline & Castilla y Leon & $1.15 \%$ & & From 1501 to 2500 euros & $25.19 \%$ \\
\hline & Community of Valencia & $1.15 \%$ & & From 2500 to 3500 euros & $16.41 \%$ \\
\hline & Others & $1.91 \%$ & & More than 3500 euros & $16.79 \%$ \\
\hline
\end{tabular}




\subsection{Descriptive Analysis}

From each of the defined security measures, a safety requirement indicator (Table 2) has been developed, which can measure the overall level of requirement for the security measures demanded and with which hypothesis 1 can be contrasted.

Table 2. Security measures and indicator.

\begin{tabular}{ccc} 
& Measures & Indicator \\
\hline SM1 & In the hotel you must respect the social distance. & \\
SM2 & The hotel must have good hygiene conditions. \\
SM3 & Employees are well-trained against COVID-19. \\
SM4 & Physical contact with employees should be avoided. & \\
SM5 & You must use your mobile phone to check into the hotel. & \\
SM6 & It is important that hotels are "immune". \\
SM7 & It is better to stay in small hotels. & \\
SM8 & The hotel must deliver a virus prevention kit. & Safety Requirement \\
SM9 & In hotels, the use of QR codes should be encouraged. & Indicator (SRI) \\
SM10 & Disinfectants such as ozone should be used in hotels. & \\
SM11 & There must be health checks. \\
SM12 & There must be official information. & \\
SM13 & The hotel must be adapted to the recommendations of the & \\
& World Health Organization (WHO) & \\
SM14 & The hotel must have a quality certification for COVID-19 & \\
SM15 & Crevention and control. & \\
SM16 & Customers should be informed about protocols and measures. & \\
SM17 & Physical contact between people must be eliminated. & \\
\hline Source: own elaboration.
\end{tabular}

From each of the defined security measures, a safety requirement indicator (Table 2) has been developed. This indicator has been obtained by the statistical transformation and recording of all security measures for which the persons were interviewed on a single scale of measurement such as the safety requirement indicator (SRI). The SRI has a dual interest in this investigation: on the one hand, it allows the overall level of demand for security measures demanded in both women and men or, in other words, how demanding hotel guests are in relation to security measures; moreover, it will be possible to accept or reject hypothesis 1 .

While the SRI allows, in a holistic way, to understand the level of demand of women and men in relation to the level of safety required against COVID-19, and whether there are differences between the sexes, at the same time, proposing a set of 17 individual hypotheses allows us to know in depth the safety measures in which women and men are most demanding and whether there are differences between the sexes.

Table 3 lists, disaggregated by sex, the main descriptive statistics of the indicator of the security requirement. For this indicator, women are found to have an average value higher than men. Something that can be put in relation to the fact that women are more sophisticated consumers and pay greater attention to details than men [30,31]. However, this difference shall be checked by the corresponding statistical test in the following subsection.

Table 3. Descriptive statistics.

\begin{tabular}{ccccccccccc}
\hline \multirow{2}{*}{\begin{tabular}{c} 
Variable \\
\cline { 2 - 10 }
\end{tabular}} & $\mathbf{N}$ & Av & SD & As & Ct & N & Av. & SD & As & Ct. \\
\hline $\begin{array}{c}\text { Safety } \\
\begin{array}{c}\text { Requirement } \\
\text { Indicator (SRI) }\end{array}\end{array}$ & 104 & 4.500 & 0.5912 & -0.719 & -0.436 & 156 & 4.744 & 0.4666 & -1.506 & 1.186 \\
Notes: Average (Av), Standard deviation (SD), Asymmetry (As), Curtosis (Ct). Source: own elaboration.
\end{tabular}


On the other hand, Table 4 shows the main descriptive statistics for each of the security measures (SM) identified in this research.

Table 4. Descriptive statistics (Classification of measures by sex).

\begin{tabular}{|c|c|c|c|c|c|c|c|c|c|c|c|c|c|}
\hline \multicolumn{7}{|c|}{ Men } & \multicolumn{7}{|c|}{ Women } \\
\hline Variable & $\mathbf{N}$ & Av & SD & As & $\mathrm{Ct}$ & Rk & Variable & $\mathbf{N}$ & Av & SD & As & $\mathrm{Ct}$ & Rk \\
\hline SM2 & 109 & 4.862 & 0.499 & -5.270 & 34.617 & 1 & SM2 & 158 & 4.981 & 0.137 & -7.117 & 49.269 & 1 \\
\hline SM13 & 109 & 4.587 & 0.735 & -2.015 & 3.932 & 2 & SM13 & 158 & 4.829 & 0.440 & -2.624 & 6.458 & 2 \\
\hline SM1 & 109 & 4.459 & 0.776 & -1.252 & 0.661 & 3 & SM16 & 158 & 4.709 & 0.611 & -1.949 & 2.489 & 3 \\
\hline SM12 & 109 & 4.404 & 0.992 & -2.106 & 4.410 & 4 & SM1 & 158 & 4.690 & 0.574 & -1.705 & 1.896 & 4 \\
\hline SM3 & 109 & 4.395 & 0.933 & -1.846 & 3.518 & 5 & SM12 & 158 & 4.684 & 0.629 & -2.432 & 7.748 & 5 \\
\hline SM16 & 108 & 4.278 & 0.874 & -1.348 & 2.215 & 6 & SM3 & 158 & 4.627 & 0.753 & -1.892 & 2.436 & 6 \\
\hline SM4 & 109 & 4.202 & 0.911 & -1.088 & 0.819 & 7 & SM14 & 158 & 4.544 & 0.834 & -2.178 & 5.182 & 7 \\
\hline SM11 & 108 & 4.194 & 0.981 & -1.189 & 0.965 & 8 & SM4 & 158 & 4.475 & 0.879 & -1.943 & 3.867 & 8 \\
\hline SM6 & 107 & 4.084 & 1.158 & -1.131 & 0.409 & 9 & SM11 & 158 & 4.437 & 0.913 & -1.794 & 3.029 & 9 \\
\hline SM14 & 109 & 4.073 & 1.069 & -1.168 & 0.846 & 10 & SM6 & 158 & 4.411 & 0.945 & -1.735 & 2.595 & 10 \\
\hline SM9 & 109 & 3.917 & 1.123 & -0.713 & -0.428 & 11 & SM10 & 158 & 4.095 & 1.199 & -1.219 & 0.565 & 11 \\
\hline SM5 & 109 & 3.881 & 1.238 & -0.874 & -0.245 & 12 & SM9 & 157 & 4.089 & 1.094 & -1.101 & 0.541 & 12 \\
\hline SM10 & 109 & 3.670 & 1.210 & -0.551 & -0.561 & 13 & SM15 & 158 & 4.089 & 1.186 & -1.195 & 0.507 & 13 \\
\hline SM15 & 109 & 3.661 & 1.256 & -0.643 & -0.538 & 14 & SM5 & 157 & 4.000 & 1.155 & -0.886 & -0.076 & 14 \\
\hline SM8 & 108 & 3.565 & 1.210 & -0.558 & -0.451 & 15 & SM17 & 158 & 3.994 & 1.159 & -0.882 & -0.195 & 15 \\
\hline SM17 & 109 & 3.523 & 1.237 & -0.398 & -0.882 & 16 & SM8 & 158 & 3.772 & 1.246 & -0.738 & -0.397 & 16 \\
\hline SM7 & 109 & 2.817 & 1.172 & 0.154 & -0.484 & 17 & SM7 & 157 & 2.975 & 1.245 & 0.089 & -0.721 & 17 \\
\hline
\end{tabular}

Notes: Average (Av). Standard deviation (SD). Asymmetry (As). Curtosis (Ct). Ranking (Rk). Source: own elaboration.

A first assessment makes it possible to verify that all safety measures, except for SM7, obtain a valuation average of more than 3.5. In the case of the SM7, a measure that assesses the possibility of considering small hotel accommodation as safer; it obtains, in both men and women, the lowest of the average ratings-even less than 3 .

Table 4 also lists the classification, according to the average assessment, of the safety measures that are considered most important according to sex. In each and every security measure, women have made higher assessments than men. If applicable, the first seven security measures they value score above 4.5 . For their part, men only place two safety measures with scores above 4.5 .

\subsection{Analysis of Differences and Hypothesis Contrasts}

In the absence of normality in the distribution of variables, contrasted with a $95 \%$ confidence level through the Kolmogorov-Smirnov test (Table 5), and assuming the heteroscedasticity of the variables, the non-parametric Mann-Whitney $U$ test has been used [72] for the contrast of the hypotheses.

Table 6 shows the results of the Mann-Whitney U test for the SRI variable, and it is noted that there is a significant difference, with a $95 \%$ confidence interval between the averages of the indicator.

Therefore, regarding hypothesis 1, this hypothesis is accepted, stating that there are differences in the means; in other words, women are more stringent in terms of the measures to be taken in hotel establishments, which also reinforces the idea that women are more demanding and detailed tourist consumers than men [31,32].

Otherwise, Table 7 shows the results of the Mann-Whitney's U test for the contrast of Hypothesis 1 to hypothesis 2.17 at a 95\% confidence level, and which of these hypotheses can be accepted or rejected.

As mentioned above, this investigation was based on the idea that women are more demanding and detailed tourist consumers than men [31,32]. This idea can be reinforced by saying that women, in addition to being more demanding than men in terms of the safety measures to be taken in hotel establishments in relation to COVID-19, are also more demanding in terms of different measures, such as good hygiene conditions, the 
use of disinfectants such as ozone, the existence of health checks and official information, adapting the establishment to WHO recommendations, obtaining quality certification for coronavirus prevention and control, measuring the temperature of customers, as well as the need to provide information to customers on protocols and measures and, finally, elimination of physical contact between people.

Table 5. Kolmogorov-Smirnov test.

\begin{tabular}{cccc}
\hline Variable & N & Test Statistic & Sig. Asymptotic (Bilateral) \\
\hline SRI & 285 & 0.421 & 0.000 \\
SM1 & 295 & 0.421 & 0.000 \\
SM2 & 297 & 0.526 & 0.000 \\
SM3 & 296 & 0.405 & 0.000 \\
SM4 & 296 & 0.331 & 0.000 \\
SM5 & 296 & 0.268 & 0.000 \\
SM6 & 295 & 0.347 & 0.000 \\
SM7 & 294 & 0.207 & 0.000 \\
SM8 & 295 & 0.199 & 0.000 \\
SM9 & 294 & 0.266 & 0.000 \\
SM10 & 294 & 0.265 & 0.000 \\
SM11 & 292 & 0.341 & 0.000 \\
SM12 & 0.405 & 0.000 \\
SM13 & 295 & 0.463 & 0.000 \\
SM14 & 295 & 0.350 & 0.000 \\
SM15 & 294 & 0.254 & 0.000 \\
SM16 & 294 & 0.406 & 0.000 \\
SM17 & 294 & 0.236 & 0.000 \\
\hline
\end{tabular}

Source: own elaboration.

Table 6. Mann-Whitney U test for Hypothesis 1.

\begin{tabular}{ccc}
\hline Variable & \multicolumn{2}{c}{ Test Statistics } \\
\hline \multirow{2}{*}{ SRI } & U & 5816.0 \\
& Sig. asymptotic (bilateral) & 0000 \\
\hline
\end{tabular}

Source: own elaboration.

Table 7. Mann-Whitney U test; and Hypothesis accepted and rejected.

\begin{tabular}{ccccc}
\hline \multirow{2}{*}{$\begin{array}{c}\text { Security } \\
\text { Measure }\end{array}$} & \multicolumn{2}{c}{ Mann-Whitney U test } & Hypothesis & Accepted or \\
\cline { 2 - 3 } & Uejected \\
\hline SM1 & 7353.0 & Sig. Asymptotic (Bilateral) & & Accepted \\
SM2 & 7902.5 & 0.012 & Hypothesis 1 & Accepted \\
SM3 & 7304.0 & 0.003 & Hypothesis 2 & Accepted \\
SM4 & 6925.0 & 0.009 & Hypothesis 3 & Accepted \\
SM5 & 8136.5 & 0.002 & Hypothesis 4 & Accepted \\
SM6 & 7160.5 & 0.468 & Hypothesis 5 & Rejected \\
SM7 & 7974.5 & 0.017 & Hypothesis 6 & Accepted \\
SM8 & 7611.5 & 0.323 & Hypothesis 7 & Rejected \\
SM9 & 7771.0 & 0.121 & Hypothesis 8 & Rejected \\
SM10 & 6715.5 & 0.175 & Hypothesis 9 & Rejected \\
SM11 & 7203.0 & 0.001 & Hypothesis 10 & Accepted \\
SM12 & 7408.5 & 0.015 & Hypothesis 11 & Accepted \\
SM13 & 7223.5 & 0.016 & Hypothesis 12 & Accepted \\
SM14 & 6260.5 & 0.002 & Hypothesis 13 & Accepted \\
SM15 & 6796.5 & 0.000 & Hypothesis 14 & Accepted \\
SM16 & 6010.0 & 0.002 & Hypothesis 15 & Accepted \\
SM17 & 6684.5 & 0.000 & Hypothesis 16 & Accepted \\
Source: 0 Own elaboration & 0.001 & Hypothesis 17 & Accepted \\
\hline
\end{tabular}


To affirm, therefore, this is relevant, as mentioned in the introduction of this investigation, if it is assumed that the rational decision-making process for the purchase of tourist goods and services is different between women and men [30].

\section{Conclusions}

The COVID-19 pandemic is causing radical changes in consumer behaviour in 2020 . In fact, one of the main sectors affected has been tourism activity, and especially hotel establishments. These establishments have had to adapt to respond to this pandemic. As a result, hotel establishments have strengthened their hygienic conditions.

This article presents the results of research conducted in Spain to learn how COVID-19 will affect the perceptions and experiences of post-COVID-19 tourists.

To analyse these results, it has been segmented by sex. As has been shown, women are more demanding than men in terms of the security measures they demand from the hotel sector. This can be found by the Safety Requirement Indicator (SRI) which reaches an average value of 4.744 for women and 4.5 for men. In addition, it is observed that women are also more existent than men in specific security measures such as SM1, SM2. SM3, SM4, SM6, SM10, SM11, SM12, SM13, SM14, SM15, SM16 and SM17.

These data have important practical applications. Those who, at first instance, enable the hotel establishment to be known as the security measures that are most concerned by their guests according to their sex. This is particularly relevant not only to provide safer accommodations, but also by finding that women are more demanding than men; it enables, to some extent, to influence women's decisions as to which accommodation they choose. Secondly, these data may be useful for tourist managers to make destinations safer.

In turn, this research makes a contribution to scientific iteration by providing statistical elements that may be of relevance to conducting this study in other countries or cities where tourism is a major economic resource. It is ultimately to contribute, through statistical instruments, to enable the tourist sector in general and the hotel sector in particular to be safer against the pandemic anywhere on the planet.

As to the limitations of this research, we could consider the following: First, the field work for data collection was carried out between April and June 2020, the period in which the first wave of COVID-19 is dated. Currently, this wave may be of no interest; however, this research has tried to obtain adequate conclusions to face the second wave of COVID-19 that the world is currently going through.

Second, the comparison of media leads to limited conclusions; in this regard, a greater number of surveys would have enabled people to be segmented in such a way as to have been possible to study their particular characteristics, such as the level of studies, to determine how far other variables besides sex condition the requirement of safety measures. Third, the field work was also carried out in April and June 2020, i.e., during the first wave of the COVID-19; once the pandemic passes through its second wave, it is appropriate to note how far the data obtained have been able to vary. Moreover, more surveys would have made possible more relevant data. Fourth, this research only analysed demand and not supply. The analysis of the supply would have made it possible to note how far the safety measures taken by the hotel sector are in line with the security measures required by its guests, thus making it possible to adapt supply with demand.

These limitations open up the possibility of future investigations. In this sense, the research team intends to conduct a study in the coming months that could demonstrate the evolution of the demands of tourists after successive waves of the pandemic. At the same time, the safety measures taken effectively in hotel facilities would enable it to determine the extent to which the hotel supply satisfies the safety expectations of its clients.

Author Contributions: Conceptualization, R.R.L., T.L.-F. and A.M.-C.; methodology, R.R.L.; software, R.R.L.; formal analysis, R.R.L.; investigation, R.R.L. and T.L.-F.; resources, A.M.-C.; writing-original draft preparation, R.R.L., T.L.-F. and, V.N.-R.; writing-review and editing, R.R.L., T.L.-F., V.N.-R. and A.M.-C.; supervision, R.R.L.; project administration, R.R.L. All authors have read and agreed to the published version of the manuscript. 
Funding: This research received no external funding.

Institutional Review Board Statement: Not applicable.

Informed Consent Statement: Not applicable.

Data Availability Statement: The data presented in this study are available on request from the corresponding author.

Conflicts of Interest: The authors declare no conflict of interest.

\section{Appendix A}

Please describe 1 to 5 (being 1 referred to "very much disagree" and 5 "very much agree") your opinion on certain measures to be taken by hotels due to COVID-19.

Table A1. Likert type question made to the people surveyed in relation to the safety measures to be taken by hotels.

\begin{tabular}{|c|c|c|c|c|c|c|}
\hline & \multirow{2}{*}{ Security Measures Required } & \multicolumn{5}{|c|}{ Importance } \\
\hline & & 1 & 2 & 3 & 4 & 5 \\
\hline 1. & The social distance must be respected at the hotel & & & & & \\
\hline 2. & The hotel must present good hygiene conditions & & & & & \\
\hline 3. & Employees must be well trained against COVID-19 & & & & & \\
\hline 4. & Physical contact with the hotel employees should be avoided & & & & & \\
\hline 5. & The mobile phone should be used to register at the hotel & & & & & \\
\hline 6. & It is important that hotels be "immune" & & & & & \\
\hline 7. & It's better to stay in small hotels & & & & & \\
\hline 8. & Hotels must deliver a virus prevention kit & & & & & \\
\hline 9. & The use of QR codes at the hotel should be extended & & & & & \\
\hline 10. & Disinfectants such as ozone should be used & & & & & \\
\hline 11. & Health controls & & & & & \\
\hline 12. & Official information & & & & & \\
\hline 13. & $\begin{array}{l}\text { Adaptation to the recommendations of the World Health } \\
\text { Organization (WHO) }\end{array}$ & & & & & \\
\hline 14. & $\begin{array}{l}\text { Quality certification for the prevention and control of } \\
\text { coronavirus }\end{array}$ & & & & & \\
\hline 15. & The temperature of the clients must be measured & & & & & \\
\hline 16. & Information received on protocols and measures & & & & & \\
\hline 17. & People contact must be eliminated & & & & & \\
\hline
\end{tabular}

\section{References}

1. Yang, Y.; Zhang, H.; Chen, X. Coronavirus pandemic and tourism: Dynamic stochastic general equilibrium modeling of infectious disease outbreak. Ann. Tour. Res. 2020, 102913. [CrossRef] [PubMed]

2. Jamal, T.; Budke, C. Tourism in a world with pandemics: Local-global responsibility and action. J. Tour. Futures 2020. [CrossRef]

3. Hoque, A.; Shikha, F.A.; Hasanat, M.W.; Arif, I.; Hamid, A.B.A. The effect of Coronavirus (COVID-19) in the tourism industry in China. Asian J. Multidiscip. Stud. 2020, 3, 52-58.

4. Buheji, M.; Ahmed, D. Foresight of Coronavirus (COVID-19) opportunities for a better world. Am. J. Econ. 2020, 10, 97-108. [CrossRef]

5. Filimonau, V.; De Coteau, D. Tourism resilience in the context of integrated destination and disaster management (DM2). Int. J. Tour. Res. 2020, 22, 202-222. [CrossRef] 
6. Del Valle, A.S. The Tourism Industry and the Impact of Covid-19, Scenarios and Proposals. Global Journey Consulting Madrid. 2020. Available online: https://worldshoppingtourism.com/downloads/GJC_THE_TOURISM_INDUSTRY_AND_THE_IMPACT_ OF_COVID_19.pdf (accessed on 18 November 2020).

7. World Travel Tourism Council. Travel \& Tourism. Economic Impact 2016; World Travel \& Tourism Council (WTTC): London, UK, 2016; p. 16.

8. Hall, C.M.; Scott, D.; Gössling, S. Pandemics, transformations and tourism: Be careful what you wish for. Tour. Geogr. 2020. [CrossRef]

9. Gössling, S.; Scott, D.; Hall, C.M. Pandemics, tourism and global change: A rapid assessment of COVID-19. J. Sustain. Tour. 2020. [CrossRef]

10. Morakabati, Y. A question of confidence. Is tourism as vulnerable to civil unrest as we think? A comparative analysis of the impact of Arab Spring on total reserves and tourism receipts. Int. J. Tour. Res. 2020, 22, 252-265. [CrossRef]

11. Pennington-Gray, L. How Will Covid-19 Affect Future Travel Behavior? A Travel Crisis Expert Explains. Available online: https: / / tinyurl.com/wcogbeh (accessed on 3 August 2020).

12. Chung, L.H. Impact of pandemic control over airport economics: Reconciling public health with airport business through a streamlined approach in pandemic control. J. Air Transp. Manag. 2015, 44, 42-53. [CrossRef]

13. Shaw, R.; Kim, Y.-K.; Hua, J. Governance, technology and citizen behavior in pandemic: Lessons from COVID-19 in East Asia. Prog. Disaster Sci. 2020, 6, 100090. [CrossRef]

14. Sohrabi, C.; Alsafi, Z.; O’Neill, N.; Khan, M.; Kerwan, A.; Al-Jabir, A.; Iosifidis, C.; Agha, R. World Health Organization declares global emergency: A review of the 2019 novel coronavirus (COVID-19). Int. J. Surg. 2020, 76, 71-76. [CrossRef] [PubMed]

15. Chinazzi, M.; Davis, J.T.; Ajelli, M.; Gioannini, C.; Litvinova, M.; Merler, S.; Piontti, A.P.Y.; Mu, K.; Rossi, L.; Sun, K. The effect of travel restrictions on the spread of the 2019 novel coronavirus (COVID-19) outbreak. Science 2020, 368, 395-400. [CrossRef] [PubMed]

16. Melián-Alzola, L.; Fernández-Monroy, M.; Hidalgo-Peñate, M. Hotels in contexts of uncertainty: Measuring organisational resilience. Tour. Manag. Perspect. 2020, 36. [CrossRef] [PubMed]

17. Davahli, M.R.; Karwowski, W.; Sonmez, S.; Apostolopoulos, Y. The Hospitality Industry in the Face of the COVID-19 Pandemic: Current Topics and Research Methods. Int. J. Environ. Res. Public Health 2020, 17, 7366. [CrossRef]

18. NSI. Hotel Tourism Short-Term Trends (HOS/HPI/IPHS). September 2020. Provisional Data. Available online: https://tinyurl. com/y6cc4dtc (accessed on 18 November 2020).

19. Shin, H.; Kang, J. Reducing perceived health risk to attract hotel customers in the COVID-19 pandemic era: Focused on technology innovation for social distancing and cleanliness. Int. J. Hosp. Manag. 2020, 91. [CrossRef] [PubMed]

20. Jiang, Y.; Wen, J. Effects of COVID-19 on hotel marketing and management: A perspective article. Int. J. Contemp. Hosp. Manag. 2020, 32, 2563-2573. [CrossRef]

21. Wang, R.; Hao, J.X. Gender Difference on Destination Image and Travel Options: An Exploratory Text-Mining Study. In Proceedings of the 15th International Conference on Service Systems and Service Management, Hang Zhou, China, 21-22 July 2018.

22. Rasoolimanesh, S.M.; Khoo-Lattimore, C.; Md Noor, S.; Jaafar, M.; Konar, R. Tourist engagement and loyalty: Gender matters? Curr. Issues Tour. 2020. [CrossRef]

23. Yang, E.C.L.; Khoo-Lattimore, C.; Arcodia, C. A systematic literature review of risk and gender research in tourism. Tour. Manag. 2017, 58, 89-100. [CrossRef]

24. López-Bonilla, J.M.; Reyes-Rodríguez, M.d.C.; López-Bonilla, L.M. Interactions and Relationships between Personal Factors in Pro-Environmental Golf Tourist Behaviour: A Gender Analysis. Sustainability 2019, 12, 332. [CrossRef]

25. Mustafa, M.H. Gender and Behavior in Archaeological Sites. Int. J. Hosp. Tour. Adm. 2015, 16, 183-201. [CrossRef]

26. Remoaldo, P.; Vareiro, L.; Cadima Ribeiro, J.; Freitas Santos, J. Does Gender Affect Visiting a World Heritage Site? Visit. Stud. 2014, 17, 89-106. [CrossRef]

27. Roman, M.; Niedziółka, A.; Krasnodębski, A. Respondents' Involvement in Tourist Activities at the Time of the COVID-19 Pandemic. Sustainability 2020, 12, 9610. [CrossRef]

28. Hong, Y.; Cai, G.; Mo, Z.; Gao, W.; Xu, L.; Jiang, Y.; Jiang, J. The Impact of COVID-19 on Tourist Satisfaction with B\&B in Zhejiang, China: An Importance-Performance Analysis. Int. J. Environ. Res. Public Health 2020, 17, 3747.

29. Han, H.; Lee, S.; Kim, J.J.; Ryu, H.B. Coronavirus Disease (COVID-19), Traveler Behaviors, and International Tourism Businesses: Impact of the Corporate Social Responsibility (CSR), Knowledge, Psychological Distress, Attitude, and Ascribed Responsibility. Sustainability 2020, 12, 8639. [CrossRef]

30. Jaffé, D. Eve-olution: Women's rising power in travel decisions. In Trends and Issues in Global Tourism 2007; Conrady, R., Buck, M., Eds.; Springer: Berlin/Heidelberg, Germany, 2007; pp. 19-31. [CrossRef]

31. Jucan, M.S.; Jucan, C.N. Gender Trends in Tourism Destination. Logos Univers. Ment. Educ. Nov. 2013, 92, 437-444. [CrossRef]

32. Evanschitzky, H.; Wunderlich, M. An Examination of Moderator Effects in the Four-Stage Loyalty Model. J. Serv. Res. 2006, 8, 330-345. [CrossRef]

33. Nientied, P.; Shutina, D. Tourism in transition, the post Covid-19 aftermath in the Western Balkans. Co-PLAN Resil. Ser. 2020, 2. [CrossRef]

34. Romagosa, F. The COVID-19 crisis: Opportunities for sustainable and proximity tourism. Tour. Geogr. 2020. [CrossRef]

35. World Tourism Organization. COVID-10 Tourism Recovery Technical Assistance Package; UNWTO: Madrid, Spain, 2020. 
36. Brouder, P. Reset redux: Possible evolutionary pathways towards the transformation of tourism in a COVID-19 world. Tour. Geogr. 2020. [CrossRef]

37. Suárez, S.; Fumero, E. La hora del turismo sostenible y de las personas. In Turismo Pos-COVID-19. Reflexiones, Retos y Oportunidades; Cátedra de Turismo Caja Canarias-Ashotel de la Universidad de La Laguna: La Laguna, Spain, 2020; pp. 283-291. Available online: https:/ / dialnet.unirioja.es/servlet/libro?codigo=770475\&orden=0\&info=open_link_libro (accessed on 18 November 2020).

38. Padrón, N.F.; Hernández, R.M. Reflexiones sobre sostenibilidad turística durante la pandemia: Una agenda para el sector frente a los ODS. In Turismo Pos-COVID-19. Reflexiones, Retos y Oportunidades; Cátedra de Turismo Caja Canarias-Ashotel de la Universidad de La Laguna: La Laguna, Spain, 2020; pp. 255-262. Available online: https://dialnet.unirioja.es/servlet/libro? codigo $=770475 \&$ orden=0\&info=open_link_libro.

39. Butler, R.W. Tourism and Resilience; CABI: Wallingford, UK, 2017.

40. Cheer, J.M.; Lew, A.A. Tourism, Resilience and Sustainability: Adapting to Social, Political and Economic Change; Routledge: Abingdon, UK, 2017.

41. Biggs, R.; Schlüter, M.; Schoon, M.L. Principles for Building Resilience: Sustaining Ecosystem Services in Social-Ecological Systems; Cambridge University Press: Cambridge, UK, 2015.

42. Berbés-Blázquez, M.; Scott, D. The development of resilience thinking. In Tourism and Resilience; CABI: Wallingford, UK, 2017; pp. 9-22.

43. Lew, A. How to Create a Better Post-COVID-19 World. Available online: https:/ / tinyurl.com/y6c8lga7 (accessed on 3 August 2020).

44. Cheer, J.M. Human flourishing, tourism transformation and COVID-19: A conceptual touchstone. Tour. Geogr. 2020. [CrossRef]

45. Gössling, S.; Hanna, P.; Higham, J.; Cohen, S.; Hopkins, D. Can we fly less? Evaluating the 'necessity'of air travel. J. Air Transp. Manag. 2019, 81, 101722. [CrossRef]

46. Hall, C.M. Constructing sustainable tourism development: The 2030 agenda and the managerial ecology of sustainable tourism. J. Sustain. Tour. 2019, 27, 1044-1060. [CrossRef]

47. Mostafanezhad, M.; Norum, R. The anthropocenic imaginary: Political ecologies of tourism in a geological epoch. J. Sustain. Tour. 2019, 27, 421-435. [CrossRef]

48. Vargas-Sánchez, A.; Moutinho, L. New strategic developments in tourism. In Strategic Management in Tourism; Moutinho, L., Vargas-Sánchez, A., Eds.; CABI Publishing: Boston, MA, USA, 2018; pp. 332-349.

49. Zeng, Z.; Chen, P.-J.; Lew, A.A. From high-touch to high-tech: COVID-19 drives robotics adoption. Tour. Geogr. 2020. [CrossRef]

50. Galvani, A.; Lew, A.A.; Perez, M.S. COVID-19 is expanding global consciousness and the sustainability of travel and tourism. Tour. Geogr. 2020. [CrossRef]

51. D'Orazio, M.; Bernardini, G.; Quagliarini, E. Sustainable and resilient strategies for touristic cities against COVID-19: An agent-based approach. arXiv Prepr. 2020, arXiv:2005.12547.

52. Gallego, I.; Font, X. Changes in air passenger demand as a result of the COVID-19 crisis: Using Big Data to inform tourism policy. J. Sustain. Tour. 2020. [CrossRef]

53. Yoo, S.-S.; Huh, M.-Y.; Min, K.-D. Women as Consumers: An Analysis on Their Consumption Culture. Int. J. Ind. Distrib. Bus. 2017, 8, 31-38. [CrossRef]

54. D'Souza, C.; Taghian, M. Female consumers as agents of change for transforming the environmental sustainability landscape. Int. J. Consum. Stud. 2017, 41, 353-360. [CrossRef]

55. Đeri, L.; Božić, S.; Šašlić, S. Analysis of gender differences in destination decision-making: The case study of Zakynthos Island. Megatrend Rev. 2017, 14, 47-62.

56. Karatsoli, M.; Nathanail, E. Examining gender differences of social media use for activity planning and travel choices. Eur. Transp. Res. Rev. 2020, 12. [CrossRef]

57. Adie, B.A.; Hall, C.M.; Prayag, G. World Heritage as a placebo brand: A comparative analysis of three sites and marketing implications. J. Sustain. Tour. 2018, 26, 399-415. [CrossRef]

58. Chen, G.; Huang, S. Understanding Chinese cultural tourists: Typology and profile. J. Travel Tour. Mark. 2018, 35, 162-177. [CrossRef]

59. Correia, A.; Kozak, M.; Ferradeira, J. From tourist motivations to tourist satisfaction. Int. J. Cult. Tour. Hosp. Res. 2013, 7, 411-424. [CrossRef]

60. Ramires, A.; Brandao, F.; Sousa, A.C. Motivation-based cluster analysis of international tourists visiting a World Heritage City: The case of Porto, Portugal. J. Destin. Mark. Manag. 2018, 8, 49-60. [CrossRef]

61. Wang, C.; Qu, H.; Hsu, M.K. Toward an integrated model of tourist expectation formation and gender difference. Tour. Manag. 2016, 54, 58-71. [CrossRef]

62. Huete-Alcocer, N.; López-Ruiz, V.R.; Grigorescu, A. Measurement of Satisfaction in Sustainable Tourism: A Cultural Heritage Site in Spain. Sustainability 2019, 11, 6774. [CrossRef]

63. European Commission. EU Guidance for the progressive resumption of tourism services and for health protocols in hospitality establishments-COVID-19, (2020/C 169/01). Off. J. Eur. Union 2020. Available online: https:/ / eur-lex.europa.eu/legal-content/ EN/TXT/?uri=CELEX\%3A52020XC0515\%2803\%29 (accessed on 3 August 2020).

64. Instituto para la Calidad Turística de España. Medidas Para la Reducción del Contagio por el Coronavirus SARS-COV-2; Ministerio de Industria, Comercio y Turismo: Madrid, Spain, 2020. 
65. González Cruz, J.P. Los hoteles ante la nueva normalidad turística: Reflexiones para el aprendizaje. In Turismo pos-COVID-19: Reflexiones, Retos y Oportunidades; Simancas, M., Hernández, R., Padrón, N., Eds.; Cátedra de Turismo CajaCanarias-Ashotel de la Universidad de La Laguna: La Laguna, Spain, 2020; pp. 417-426.

66. Finn, M.; Walton, M.; Elliott-White, M. Tourism and Leisure Research Methods: Data Collection, Analysis, and Interpretation; Pearson Education: London, UK, 2000.

67. Nunnally, J.; Bernstein, I. Psychometric Theory; McGraw-Hill: New York, NY, USA, 1994.

68. Observatorio Nacional de Turismo. Informe Verano 2020. Hábitos y Comportamiento del Turista Nacional; Observatorio Nacional de Turismo: Madrid, Spain, 2020.

69. DNA Turismo y Ocio. En Busca de Escenarios y Recetas Para las Nuevas Fases que Definirán una Nueva era del Turismo; La Industria Turística y el COVID 19; DNA Turismo y Ocio: Madrid, Spain, 2020.

70. DNA Turismo y Ocio. Segunda Investigación: "La Opinión de la Demanda": Intención de Compra de Productos y Servicios Turísticos. Nuevos Hábitos de Consumo Turístico; La Industria Turística y el COVID 19; DNA Turismo y Ocio: Madrid, Spain, 2020.

71. IBM Corp. IBM SPSS Statistics for MAC Os; Version 25.0. Released 2017; IBM Corp.: Armonk, NY, USA, 2017.

72. Mann, H.B.; Whitney, D.R. On a test of whether one of two random variables is stochastically larger than the other. Ann. Math. Stat. 1947, 18, 50-60. [CrossRef] 